\title{
EFFECTS OF LIGHT, TEMPERATURE AND MESOCARP ON SEED GERMINATION OF Euterpe edulis (JUÇARA-PALM)
}

\author{
EFEITO DA LUZ, TEMPERATURA E MESOCARPO NA GERMINAÇÃO DE \\ SEMENTES DE PALMITO JUÇARA (Euterpe edulis)
}

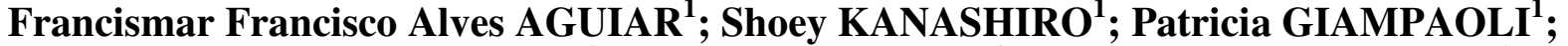 \\ Valeria Aparecida MODOLO ${ }^{2}$; Janaína de AGUIAR ${ }^{3}$; Armando Reis TAVARES ${ }^{1}$ \\ 1. Instituto de Botânica, São Paulo, SP, Brasil; 2. Instituto Agronômico de Campinas, Campinas, SP, Brasil; 3. Universidade Federal do \\ Amazonas, Manaus, AM, Brasil. atavares2005@yahoo.com.br
}

\begin{abstract}
The study exposed in this paper aimed at evaluating the influence of light, temperature and presence or absence of mesocarp in seeds on the germination of Euterpe edulis Mart. (juçara-palm). The germination of seeds with and without mesocarp was assessed in the presence of light (12 h photoperiod) or in the darkness, and at temperatures of 25,28 or $30 \mathrm{C}$. A complete randomized $2 \times 2 \times 3$ (mesocarp presence, light conditions and temperatures) factorial design was used. The seed germinability and the Germination Speed Index (GSI) were evaluated. Seeds of $E$. edulis were indifferent either to the presence of light or to temperatures of 25, 28 and 30C. The germinability of the seeds with mesocarp was lower (6 to $10 \%$ ) than those without mesocarp (47 to $75 \%$ ).
\end{abstract}

KEYWORDS: Heart of palm. Arecaceae. Forest Seeds. Atlantic Forest. Arecaceae.

\section{INTRODUCTION}

Euterpe edulis Mart., Arecaceae (juçarapalm) is traditionally used in heart of palm extraction. This kind of palm established the heart of palm market in Brazil about 20 years ago, and has dominated it since then, developing the concept of the product in the consumer's mind (what the real taste of heart of palm is), which includes tying its consumption to canned food (industrialized heart of palm). E. edulis may be found from the states of Bahia to Rio Grande do Sul, in Brazil, and due to its predatory extraction, it is in the official list of endangered species and under extinction threat in the state of São Paulo (MAMEDE et al., 2007).

The heart of palm cultivation for food production is, undoubtedly, one of the few commercially cultivated plants that can be grown in native forests with minimal investment, since its cultivation may be achieved through sustainable management in areas of natural occurrence and regulated by specific legislation. The species is also considered a key one for the sustainable management of native formations in the Atlantic Forest (CARVALHO, 2003).

The palm has received much attention in recent years due to the extremely high anti-oxidant capacity of its fruit pulp (mesocarp) and its role as a "functional food" or food ingredient (KANGA, 2010). The fruits are rich in vitamins, minerals, trace elements, soluble and insoluble fiber, phytosterols (betasitosterol, campesterol, and sigmasterol), and low-sugar content (SCHAUSS et al., 2009). The species is also used in civil construction, for cellulose production, animal feeding and compost, landscape architecture, human food and, due to its high potential for regeneration, is also recommended for recovering degraded areas (CARVALHO, 2003; MAMEDE et al., 2007).

Guerra et al. (1984) pointed out the importance of E. edulis and the need for further specific studies concerning its conservation, seed vigor, efficiency of germination and nursery management, allowing an improvement in the current knowledge regarding native forest trees. Seed germination in natural conditions is slow, though the removal of the mesocarp from the fruit promotes not only a homogenous seed germination rate, but also the acceleration of the germination process (QUEIROZ, 2000).

Bearing in mind the ecological and economical importance of such species, the objective of this study was to evaluate the germination response of its seeds to different temperature regimes and light conditions, as well as the efficiency of its propagation under such conditions.

\section{MATERIAL AND METHODS}

Ripened fruits of E. edulis, recognized by the black colour, were harvested from 10 specimens cultivated at the Botanical Garden of São Paulo. Fruits were divided in two lots, and one of them had the seeds depulped through friction against a steel 
mesh sieve, under running water (seeds without mesocarp).

All seeds were soaked in a benomyl 80 at $0.1 \%$ solution for $8 \mathrm{~h}$, and subsequently air-dried for $48 \mathrm{~h}$, intended for pathogenic fungi preventive control. Seeds water contents were $40.85 \%$ for seeds with mesocarp and $36.64 \%$ for seeds without mesocarp, and were determined gravimetrically (Brasil, 2009), using two replications of 20 seeds at $105 \pm 3{ }^{\circ} \mathrm{C}$ for 24 hours, with results expressed in percentage (wet basis). Seeds were sowed in either transparent (light) or black (darkness)

Gerbox plastic boxes $(11.0 \times 11.0 \times 3.5 \mathrm{~cm})$, containing vermiculite as substrate, fully moistened with distilled water. The boxes were kept in B.O.D. chambers at three different constant temperatures $\left(25,28\right.$ or $\left.30{ }^{\circ} \mathrm{C}\right)$ and with two lighting treatments (12 $\mathrm{h}$ photoperiod $-25 \mu \mathrm{mol} \mathrm{m} \mathrm{m}^{-2} \mathrm{~s}^{-1}$ photosynthetic active radiation (PAR) and total darkness). The assessment of seed germination was carried out in a dark chamber (green light was used to access the seeds). The count of germinated seeds was performed weekly (it started with the first seed germinated), and last for 63 days. The criteria used to evaluate seed germination was the formation of a normal plantlet, according to Borguetti and Ferreira (2004).

Statistical analysis: based in a completely randomized in a $2 \times 3 \times 2$ factorial design (seeds with or without mesocarp, temperature and light), totalling 12 treatments with four replications of 25 seeds each one. Normality and homogeneity of data were analysed with the Shapiro-Wilk test, with no need for transformation. Data were subjected to variance analysis and averages were compared by Tukey's test $(p \leq 0.05)$.

\section{RESULTS AND DISCUSSION}

The germinability of seeds with mesocarp, both under light and dark conditions and at different temperatures, were lower when compared to seeds without mesocarp (Table 1). The presence of mesocarp significantly reduced the seed germinability, when compared to seeds without mesocarp. The same results were obtained by Bovi and Cardoso (1976), who concluded that seeds of $E$. edulis, with or without mesocarp, submitted to scarification with $\mathrm{H}_{2} \mathrm{SO}_{4}$, showed the highest seed germinability. The removal of mesocarp seeds from green fruits of Dypsis lutescens (Palmae) greatly decreased seed germinability, suggesting that the presence of mesocarp may be important for maturation of an immature embryo (BROSCHAT; DONSELMAN, 1986). These results support the importance of animals eating the mesocarp (pulp) of fruits, as the germination rates and the seedling formation increase when the pulp passes through the digestive tract of animals (REIS; KAGEYAMA, 2000). E. edulis is also important for the preservation of some birds species, which eat the fruits of this palm and disperse their seeds (COIMBRA-FILHO et al., 1998). However, the presence of mesocarp is prejudicial on seed storage, once it is oleaginous and rich in sugars, allowing microorganisms to develop and seed coat fermentation, causing embryo damage and, consequently, viability loss and germination rate reduction (MARTINS et al., 2004).

Table 1. Means of Euterpe edulis seeds with and without mesocarp germinability, light or darkness and at three different temperatures. São Paulo, IBt, 2010.

\begin{tabular}{lc}
\hline Treatments & Germinability $(\%)$ \\
\hline Seeds with mesocarp & $7.83 \mathrm{~B}$ \\
Seeds without mesocarp & $60.83 \mathrm{~A}$ \\
\hline Darkness & $33.17 \mathrm{a}$ \\
Light & $35.50 \mathrm{a}$ \\
\hline $25^{\circ} \mathrm{C}$ & $38.00 \mathrm{a}$ \\
$28{ }^{\circ} \mathrm{C}$ & $29.25 \mathrm{a}$ \\
$30^{\circ} \mathrm{C}$ & $35.75 \mathrm{a}$ \\
\hline
\end{tabular}

Seeds without mesocarp showed higher physiological qualities than those with mesocarp as supported by the higher germinability. The speed of germination of palm seeds with oily mesocarp is lower and, consequently, was related to the final seed germinability (BOVI et al., 1987).
Seeds with and without mesocarp of $E$. edulis germinated equally under light and darkness. This result is similar to those reported by Tavares $e t$ al. (2008), who did not report any effect of different levels of lighting $(0,20,40,60$ or $80 \%$ of shading) on seed germination of E. edulis. Aguiar et al. 
(2005), studying the effect of temperature, light and compost on the seed germination of Rhapis excelsa (Palmae) concluded that total darkness benefitted the germinability, as well as the temperature of 25 ${ }^{\circ} \mathrm{C}$ allowed not only the best germination, but also the fastest plantlets development.

Seed germination of E. edulis was not statiscally different between seeds with or without mesocarp at the temperatures of 25,28 or $30^{\circ} \mathrm{C}$. These results are similar to those reported by Bovi and Cardoso (1976) and Bovi et al. (1987), when they studied the effect of light and temperature on the germination of E. edulis. Andrade et al. (1999) observed higher germination rates, number of normal plants, and speed of plantlet germination for E. edulis at the temperatures of $20-30$ and $25{ }^{\circ} \mathrm{C}$ when compared to higher temperatures $(30,35$ and 20-35 ${ }^{\circ} \mathrm{C}$ ). Seeds of E. edulis (MARTINS et al., 2004) and E. oleracea (ARAÚJO et al., 1994), for instance, showed characteristics of recalcitrant seeds, not adaptable to desiccation and/or storage at low temperature, leading to very low germinability and short longevity. E. edulis seeds lost their germination power after seed moisture decay to $20 \%$, condition that was created after 16 days drying at room temperature and relative humidity (REIS et al., 1999).

The results showed that the mesocarp of $E$. edulis could be an evolutionary strategy, of exceptional ecological importance, as it makes feasible seeds germination at both summer and autumn temperatures in Brazil, seasons that coincide with fruit maturation and seed dispersion. Development of plantlets of E. edulis after germination may benefit from open spaces in the forest, due to their plasticity to increase their efficacy in uptaking nutrients and liquid carbon under higher luminescence (ILLENSEER; PAULILO, 2002).

\section{CONCLUSIONS}

There is no interaction between temperature and luminosity for E. edulis seeds germinability.

The presence of the mesocarp on E. edulis seeds reduces seed germinability.

Seeds without mesocarp showed the best results for seed germinability and velocity of germination aiming at E. edulis propagation by seeds.

RESUMO: O objetivo deste estudo foi avaliar a influência da luz, temperatura na germinação do fruto com ou sem mesocarpo (despolpado) de Euterpe edulis Mart. (palmiteiro-juçara). Sementes com e sem mesocarpo foram submetidas a presença de luz (fotoperíodo de $12 \mathrm{~h}$ ) ou escuro contínuo e às temperaturas de 25,28 ou $30{ }^{\circ} \mathrm{C}$. $\mathrm{O}$ delineamento experimental foi inteiramente casualizado, em arranjo fatorial 2x2x3 (presença de mesocarpo, regimes de luz e temperaturas). Avaliou-se a germinabilidade e o índice de velocidade de germinação das sementes (IVG). As sementes de E. edulis comportaram-se indiferentes à luz e às temperaturas de 25,28 e $30{ }^{\circ} \mathrm{C}$. A germinabilidade das sementes com mesocarpo foi menor (6 a 10\%) que das sementes sem mesocarpo (47 a 75\%).

PALAVRAS CHAVE: Palmito. Sementes Florestais. Floresta Atlântica. Arecaceae.

\section{REFERENCES}

CALVI, G. P.; TERRA, G.; PIÑA-RODRIGUES, F. M. C. Germinação e estabelecimento de sementes de Euterpe edulis Mart. em floresta ombrófila densa montana no município de Miguel Pereira, RJ. Revista da Universidade Rural, Série Ciência e Vida, Seropédia, v. 24, n. 1, p. 107-113, 2004.

AGUIAR, F. F. A.; BILIA, D. A. C.; KANASHIRO, S.; TAVARES, A. R.; BARBEDO, C. J. Germinação de sementes de Rhapis excelsa (Thumb.) Henry ex. Render: efeitos da temperatura, luz e substrato. Hoehnea, São Paulo, v. 32, n. 1, p. 119-126, 2005.

ANDRADE, A. C. S. Reavaliação do efeito do substrato e da temperatura na germinação de sementes de palmiteiro (Euterpe edulis Mart.). Revista Árvore, Viçosa. v. 23, n. 3, p. 279-283, 1999.

ARAÚJO, E. F.; SILVA, R. F.; ARAÚJO, R. F. Avaliação da qualidade de sementes de açaí armazenadas em diferentes embalagens e ambientes. Revista Brasileira de Sementes, Viçosa, v. 16, n. 1, p. 76-79, 1994. https://doi.org/10.17801/0101-3122/rbs.v16n1p76-79 
BORGHETTI, F.; FERREIRA, A. G. Interpretação de resultados de germinação. In: FERREIRA, A. G.; BORGHETTI, F. (Coord.). Germinação: do básico ao aplicado. Porto Alegre: Artmed, 2004. p. 209-222.

BOVI, M. L. A.; CARDOSO, M. Germinação de sementes de palmiteiro (Euterpe edulis Mart). Bragantia, Campinas, v. 35, p. XXIII-XXIX, (nota n o 06), 1976. https://doi.org/10.1590/S0006-87051987000200014

BOVI, M. L. A.; SAES, L. A.; CIONE, M. C. J. Densidade de plantio de palmiteiro em regime de sombreamento definitivo. Bragantia, Campinas, v. 46, n. 2, p. 329-341, 1987.

BRASIL. Ministério da Agricultura, Pecuária e Abastecimento. Regras para análise de sementes. Brasília: Mapa/ACS, 2009. 395p.

BROSCHAT, T. K.; DONSELMAN, H. Factors affecting storage and germination of Chrysalidocarpus lutescens seeds. Journal of the American Society for Horticultural Science, Alexandria, v. 111, n. 6, p. 872 $877,1986$.

CARVALHO, P. E. R. Espécies arbóreas brasileiras. Colombo: Embrapa Florestas, 2003. 644p.

COIMBRA-FILHO, A. F.; SILVA, R. R.; SILVA, A. R. 1998. A juçara (Euterpe edulis Mart.): Ensaios e apontamentos conservacionistas. Boletim FBCN, Rio de Janeiro, v. 25, p. 99-117.

GUERRA, M. P.; NODARI, R. O.; REIS, A. Considerações sobre o palmiteiro no sul do Brasil. Insula, Florianópolis, v. 14, p. 171-180, 1984.

ILLENSEER, R.; PAULILO, M. T. S Crescimento e eficiência na utilização de nutrientes em plantas jovens de Euterpe edulis Mart. sob dois níveis de irradiância, nitrogênio e fósforo. Acta Botanica Brasilica, São Paulo, v. 16, n. 4, p. 385-394, 2002. https://doi.org/10.1590/S0102-33062002000400002

KANGA, J.; LIB, Z.; WUB, T.; JENSENC, G. S.; SCHAUSSD, A. G.; WU, X. Anti-oxidant capacities of flavonoid compounds isolated from acai pulp (Euterpe oleracea Mart.). Food Chemistry, Amsterdam, v. 122, n. 3, p. 610-617, 2010. https://doi.org/10.1016/j.foodchem.2010.03.020

MAGUIRE, J. B. Speed of germination-aid in selection and evaluation for seedling emergence vigor. Crop Science, New York, v. 2, n. 2, p. 176-177, 1962.

https://doi.org/10.2135/cropsci1962.0011183X000200020033x

MAMEDE, M. C. H.; SOUZA, V. C.; PRADO, J.; BARROS, F.; WANDERLEY, M. G. L.; RANDO, J. G. Livro vermelho das espécies vegetais ameaçadas do Estado de São Paulo. São Paulo: Instituto de Botânica, 2007. 165p.

MARTINS, C. C.; BOVI, M. L. A.; NAKAGAWA, J.; GODOY JÚNIOR, G. Temporary storage of jussara palm seeds: effects of time, temperature and pulp on germination and vigor. Horticultura Brasileira, Brasília, v. 22, n. 2, p. 271-276, 2004. https://doi.org/10.1590/S0102-05362004000200021

QUEIROZ, M. H. Biologia do fruto, da semente e da germinação do palmiteiro (Euterpe edulis Mart.). In: REIS, M. S.; REIS, A. (eds). Euterpe edulis Mart. (palmiteiro): biologia, conservação e manejo. Itajaí: Herbário Barbosa Rodrigues, 2000. p. 39-59.

REIS, A.; KAGEYAMA, P. Y. Dispersão de sementes do palmiteiro (Euterpe edulis Mart. - Palmae). In: REIS, M. S.; REIS, A. (eds). Euterpe edulis Mart. (palmiteiro): biologia, conservação e manejo. Itajaí: Herbário Barbosa Rodrigues, 2000. p. 60-92.

REIS, A.; PAULILO, M. T. S.; NAKAZONO, E. M.; VENTURI, S. Efeito de diferentes níveis de dessecamento na germinação de sementes de Euterpe edulis Martius-Arecaceae. INSULA Revista de Botânica, Florianópolis, v. 28, p. 31-42, 1999. 
SCHAUSS, A. G.; WU, X.; JENSEN, G. S. Increased antioxidant capacity and inhibition of lipid peroxidation in healthy adults consuming an acai (Euterpe oleracea) fruit-based juice. Acta Horticulturae, Amsterdam v. 841, p. 97-100, 2009. https://doi.org/10.17660/ActaHortic.2009.841.9

TAVARES, A. R.; RAMOS, D. P.; AGUIAR, F. F. A.; KANASHIRO, S. Jussara-palm seed germination under different shade levels. Horticultura Brasileira, Brasília, v. 26, n. 4, p. 492-494, 2008.

https://doi.org/10.1590/S0102-05362008000400013 